\title{
Influence of polymer-coated slow-release urea on total tract apparent digestibility, ruminal fermentation and performance of Nellore steers
}

\author{
R. Gardinal ${ }^{1}$, G. D. Calomeni ${ }^{1}$, N. R. B. Cônsolo ${ }^{1}$, C. S. Takiya ${ }^{1}$, J. E. Freitas Jr ${ }^{2}$, J. R. Gandra ${ }^{3}$, \\ T. H. A. Vendramini ${ }^{1}$, H. N. Souza ${ }^{4}$, and F. P. Rennó ${ }^{1, *}$
}

\footnotetext{
* Corresponding Author: F. P. Rennó Tel: +55-19-3565-4248, Fax: +55-19-3565-4300, E-mail: francisco.renno@usp.br

'Department of Animal Nutrition and Production, School of Veterinary Medicine and Animal Science, University of Sao Paulo (USP), Pirassununga, SP 13635-900, Brazil

2 Department of Animal Sciences, Federal University of Bahia, Salvador, BA 40170-110, Brazil

${ }^{3}$ Department of Animal Sciences, Universidade Federal da Grande Dourados, Dourados, MS 79804-970, Brazil

4 Petrobrás, CENPES, 21040-000, Rio de Janeiro, RJ, Brasil
}

Submitted Jan 23, 2016; Revised Apr 4, 2016; Accepted Apr 26, 2016
Objective: Two experiments were performed to evaluate the effects of coated slow-release urea on nutrient digestion, ruminal fermentation, nitrogen utilization, blood glucose and urea concentration (Exp 1), and average daily gain (ADG; Exp 2) of steers.

Methods: Exp 1: Eight ruminally fistulated steers [503 $\pm 28.5 \mathrm{~kg}$ body weight (BW)] were distributed into a d $4 \times 4$ Latin square design and assigned to treatments: control (CON), feed grade urea (U2), polymer-coated slow-release urea A (SRA2), and polymer-coated slow-release urea B (SRB2). Dietary urea sources were set at $20 \mathrm{~g} / \mathrm{kg}$ DM. Exp 2: 84 steers (350.5 $\pm 26.5 \mathrm{~kg}$ initial BW) were distributed to treatments: CON, FGU at 10 or $20 \mathrm{~g} / \mathrm{kg}$ diet DM (U1 and U2, respectively), coated SRA2 at 10 or $20 \mathrm{~g} / \mathrm{kg}$ diet DM (SRA1 and SRA2, respectively), and coated SRB at 10 or $20 \mathrm{~g} / \mathrm{kg}$ diet DM (SRB1 and SRB2, respectively).

Results: Exp 1: Urea treatments (U2+SRA2+SRB2) decreased $(7.4 \%, \mathrm{p}=0.03)$ the DM intake and increased $(11.4 \%, \mathrm{p}<0.01)$ crude protein digestibility. Coated slow-release urea (SRA2+SRB2) showed similar nutrient digestibility compwared to feed grade urea (FGU). However, steers fed SRB2 had higher $(p=0.02)$ DM digestibility compared to those fed SRA2. Urea sources did not affect ruminal fermentation when compared to CON. Although, coated slow-release urea showed lower $(\mathrm{p}=0.01)$ concentration of $\mathrm{NH}_{3}-\mathrm{N}(-10.4 \%)$ and acetate to propionate ratio than $\mathrm{U} 2$. Coated slow-release urea showed lower $(\mathrm{p}=0.02)$ urinary N and blood urea concentration compared to FGU. Exp 2: Urea sources decreased $(p=0.01)$ the ADG in relation to CON. Animals fed urea sources at $10 \mathrm{~g} / \mathrm{kg}$ DM showed higher $(12.33 \%, \mathrm{p}=0.01)$ ADG compared to those fed urea at $20 \mathrm{~g} / \mathrm{kg} \mathrm{DM}$.

Conclusion: Feeding urea decreased the nutrient intake without largely affected the nutrient digestibility. In addition, polymer-coated slow-release urea sources decreased ruminal ammonia concentration and increased ruminal propionate production. Urea at $20 \mathrm{~g} / \mathrm{kg} \mathrm{DM}$, regardless of source, decreased ADG compared both to CON and diets with urea at $10 \mathrm{~g} / \mathrm{kg}$ DM.

Keywords: Slow-release Urea, Ammonia, Average Daily Gain, Non-protein Nitrogen

\section{INTRODUCTION}

Non-protein nitrogen is an alternative to partially replace true protein sources (i.e. soybean meal) in ruminant diets, decreasing feed cost and maintaining animal performance [1]. Among the non-protein nitrogen sources, urea is the most used in cattle diets to achieve $\mathrm{N}$ requirements of rumen microorganisms [2]. However, urea can be rapidly hydrolyzed to ammonia in rumen and exceeds the capacity of its conversion into microbial $\mathrm{N}$, because the rate of carbohydrate fermentation is slower than the rate of urea hydrolysis [3]. The ammonia can

\section{www.ajas.info}


be absorbed by ruminal epithelium, metabolized into urea by the liver, and excreted in urine increasing the $\mathrm{N}$ losses [4].

Slow-release urea has decreased the appearance of ammonia in rumen fluid and has not showed peaks of it in ruminal concentration as observed when animals are supplied feed grade urea, suggesting a greater $\mathrm{N}$ utilization by rumen microorganisms [5]. Positive effects of feeding slow-release urea (SRU) on neutral detergent fiber (NDF) digestibility and microbial protein synthesis have been reported in literature [6]. These effects are related to the fact that several cellulolytic bacteria use $\mathrm{N}$ from ammonia to grow in rumen [7]. However, other studies have reported no effects of replacing feed grade urea by SRU on ruminal fermentation [8], nutrient digestibility and $\mathrm{N}$ excretion [9].

The objective of this study was to determine the influence of two different polymer-coated slow-release urea on nutrient intake and total tract apparent digestibility, ruminal fermentation, $\mathrm{N}$ utilization, microbial protein synthesis, blood glucose and urea concentration of Nellore steers (Exp 1). The second experiment was designed to evaluate the effects of two different polymer-coated slow release urea at two levels on average daily gain (ADG), rib-eye area, and backfat thickness of Nellore steers (Exp 2). Our hypothesis was that coated slow-release urea sources would decrease ruminal $\mathrm{NH}_{3}-\mathrm{N}$ concentration, improve NDF total tract apparent digestibility, and consequently improve animal performance compared to those animals fed feed grade urea.

\section{MATERIALS AND METHODS}

This study was conducted with permission of the Bioethics Committee of School of Veterinary Medicine and Animal Science, University of Sao Paulo (approval number: 1909/2010).

\section{Experiment 1}

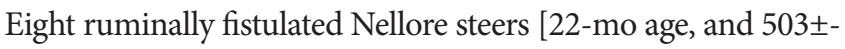
$28.5 \mathrm{~kg}$ body weight (BW), mean \pm standard deviation (SD)] were randomly assigned into a replicated $4 \times 4$ Latin square design consisting of 7 days for diet adaptation [10] and 4 days for sampling and data collection. Steers were distributed to receive one of the following diets: control $(\mathrm{CON})$, feed grade urea (U2, Reforce N, Petrobras, Rio de Janeiro, Brazil), polymer-coated slow-release urea A (SRA2, Polymer-coated slowrelease urea without sulphur in composition, Petrobras, Rio de Janeiro, Brazil), and polymer-coated slow-release urea B (SRB2, Polymer-coated slow-release urea with $29.5 \mathrm{~g} / \mathrm{kg} \mathrm{DM}$ of sulphur content, Petrobras). Dietary urea, regardless of the source, was set at $20 \mathrm{~g} / \mathrm{kg}$ DM. Experimental diets (Table 1) were formulated to be isonitrogenous and to achieve nutrient requirements of Bos indicus steers with $500 \mathrm{~kg}$ BW for an ADG of $0.8 \mathrm{~kg}$ according to NRC [11]. Animals received experimental diets as a total mixed ration at $0700 \mathrm{~h}$ and $1300 \mathrm{~h}$ (50:50).
Table 1. Ingredients and chemical composition of experimental diets (Experiment 1)

\begin{tabular}{lllll}
\hline \multirow{2}{*}{ Item } & \multicolumn{4}{c}{ Diet $^{1)}$} \\
\cline { 2 - 5 } & CON & U2 & SRA2 & SRB2 \\
\hline Ingredient (\%) & 50.2 & 50.0 & 50.0 & 50.0 \\
$\quad$ Corn silage & () & & & \\
$\quad$ Ground corn & 31.2 & 44.1 & 44.1 & 44.1 \\
$\quad$ Soybean meal 48\% crude protein & 10.6 & & & \\
$\quad$ Whole raw soybean & 5.80 & 1.70 & 1.70 & 17.0 \\
Urea & & 2.00 & & \\
Slow release urea A & & & 2.00 & \\
Slow release urea B & & & & 2.00 \\
$\quad$ Mineral premix) & 1.98 & 1.98 & 1.98 & 1.98 \\
$\quad$ Limestone & 0.11 & 0.11 & 0.11 & 0.11 \\
$\quad$ Salt & 0.11 & 0.11 & 0.11 & 0.11 \\
Chemical composition (\% DM) & & & & \\
$\quad$ Dry matter (\% as fed) & 63.0 & 62.9 & 62.9 & 62.9 \\
$\quad$ Neutral detergent fiber & 32.3 & 31.7 & 31.7 & 31.7 \\
Acid detergent fiber & 21.7 & 20.5 & 20.5 & 20.5 \\
$\quad$ Crude protein & 15.3 & 15.1 & 15.1 & 15.1 \\
$\quad$ Ether extract & 3.61 & 2.82 & 2.82 & 2.82 \\
\hline
\end{tabular}

$\mathrm{DM}$, dry matter; $\mathrm{CP}$, crude protein; $\mathrm{DM}$, dry matter.

1) Control, CON; U2, $20 \mathrm{~g} / \mathrm{kg}$ DM of feed grade urea; SRA2, $20 \mathrm{~g} / \mathrm{kg}$ DM of polymer-coated slow release A; SRB2, $20 \mathrm{~g} / \mathrm{kg}$ DM of polymer coated slow release $B$.

${ }^{2)}$ Average chemical composition (\% DM): 34.8 DM (\% as fed), 9.68 crude protein, 52.4 neutral detergent fiber, and 30.6 non-fiber carbohydrate.

${ }^{3)}$ Contained per kilogram: 160 g Ca, 24 g P, 5 g Mg, 59.3 g Na, 28 g S, 8.23 g Co, 560 $\mathrm{mg} \mathrm{Cu}, 28 \mathrm{mg} \mathrm{I}, 11,20 \mathrm{mg} \mathrm{Mn}, 5.6 \mathrm{mg} \mathrm{Se}, 1,680 \mathrm{mg}$ Zn.

Throughout the experiment, animals were housed in individual pens $\left(17.5 \mathrm{~m}^{2}\right)$, containing sand beds, feed bunks, free access to water and forced ventilation. At the start of the experiment, and on days 8 and 11 of each period steers were weighed in a livestock scale for large animals.

Feed offered and orts of each animal were weighed daily to determine feed intake and to maintain refusals between $5 \%$ to $10 \%$ (on as fed-basis). Samples of all diet ingredients $(0.5 \mathrm{~kg})$ and orts ( 3 samples, $12.5 \%$ of total daily orts) from each steer were collected on days 8 to 11 and composited into one sample. Fecal samples of each steer were collected directly from the rectum twice daily (at $0800 \mathrm{~h}$ and $1600 \mathrm{~h}$ ) on days 8 to 11 , and samples were combined (on a wet basis) to form a composite sample. All samples were stored at $-20^{\circ} \mathrm{C}$ to further chemical analyses.

Samples were dried at $55^{\circ} \mathrm{C}$ in a forced-air oven during 72 $\mathrm{h}$ and ground in a knives mill to pass through a $2 \mathrm{~mm}$ and 1 mm screen (Wiley Mill, A. H. Thomas, Philadelphia, PA, USA). Dry matter (AOAC 950.15), crude protein (CP, N×6.25, AOAC 984.13), and ether extract (EE, AOAC 920.39) were analyzed in all samples according to AOAC [12]. The NDF (using $\alpha$-amylase and no sodium sulphite) and acid detergent fiber (ADF) were assessed according to Van Soest et al [13] in a fiber analyzer (TE-149, Tecnal Equipments for Laboratory Inc., Piracicaba, Brazil).

The DM fecal excretion $(\mathrm{kg} / \mathrm{d})$ was estimated using the in- 
digestible ADF (iADF) as an internal marker according to Casali et al [14]. Ground samples (2 mm screen) of feed ingredients, orts, and feces were placed in non-woven fabric tissue bags ( $100 \mathrm{~g} \mathrm{DM} / \mathrm{m}^{2}$ with $5 \times 5 \mathrm{~cm}$ of dimension) and incubated in the rumen of two fistulated Nellore steers previously adapted to the CON treatment of the current study. After 288 $\mathrm{h}$ of incubation, the bags were removed from the rumen and washed in running tap water, dried at $55^{\circ} \mathrm{C}$ in a forced-air oven for $72 \mathrm{~h}$ and then submitted to ADF analysis, as previously described. The total tract apparent digestibility was calculated as follows:

$$
\text { Digestibility of DM }=100-\left[100 \times\left(\frac{\% \text { iADF in diet }}{\% \text { iADF in feces }}\right)\right]
$$

\section{Digestibility of nutrient}

$$
=100-\left[100 \times\left(\frac{\% \text { iADF in diet }}{\% \text { iADF in feces }}\right) \times\left(\frac{\% \text { nutrient in feces }}{\% \text { nutrient in diet }}\right)\right]
$$

On day 11 of each experimental period, ruminal fluid samples $(200 \mathrm{~mL})$ were collected before the morning feeding $(0 \mathrm{~h})$ and $2,4,6,8,10$, and $12 \mathrm{~h}$ after the morning feeding straining rumen digesta (collected from posterior ventral, posterior dorsal, medium ventral, anterior ventral, and anterior dorsal sites) in four layers of cheese cloth [15]. Immediately after each sampling, ruminal fluid $\mathrm{pH}$ was determined using a potentiometer (MB-10, Marte, Santa Rita do Sapucaí, Brazil). Aliquots of ruminal fluid $(1,600 \mu \mathrm{L})$ were mixed within methanoic acid (400 $\mu \mathrm{L}, 98 \%$ to $100 \% \mathrm{H}_{2} \mathrm{CO}_{2}$ ), and then centrifuged at $7,000 \times \mathrm{g}$ for $15 \mathrm{~min}$. The supernatant was collected and stored at $-20^{\circ} \mathrm{C}$ for short chain fatty acid (SCFA) analyses. Other aliquots of ruminal fluid $(2 \mathrm{~mL})$ were mixed within sulfuric acid $(1 \mathrm{~mL}, 0.5 \mathrm{Mol} / \mathrm{L}$ $\mathrm{H}_{2} \mathrm{SO}_{4}$ ) and stored at $-20^{\circ} \mathrm{C}$ for subsequent analysis of $\mathrm{NH}_{3}-\mathrm{N}$ by the colorimetric phenol-hypochlorite method [16].

A gas chromatograph (GC-2014, Shimadzu, Tokyo, Japan) equipped with a capillary column Stabilwax, Restek, Bellefonte, PA, USA) was used to assess SCFA concentration in ruminal fluid. Helium was used as the carrier gas (flowing at $8.01 \mathrm{~mL} /$ $\mathrm{min}$ ), hydrogen was used as the fuel gas with a pressure of 60 $\mathrm{kPa}$, and synthetic air was used as the oxidizer gas with a pressure of $40 \mathrm{kPa}$. Temperatures of steamer and ionization detector flame were $220^{\circ} \mathrm{C}$ and $250^{\circ} \mathrm{C}$, respectively. The temperature of separation column was set at $145^{\circ} \mathrm{C}$ and then raised $10^{\circ} \mathrm{C} / \mathrm{min}$ up to $200^{\circ} \mathrm{C}$.

Urine samples $(200 \mathrm{~mL})$ were collected $4 \mathrm{~h}$ after the morning feeding on day 11 of each experimental period. Aliquots $(10 \mathrm{~mL})$ of urine were diluted in sulfuric acid $(40 \mathrm{~mL}, 0.036 \mathrm{~N})$ in order to avoid the destruction of purine derivatives (PD) and uric acid precipitation. Samples were used for N, creatinine, uric acid and allantoin determination. Creatinine concentrations were obtained by enzymatic colorimetric method using commercial kits (Labor- lab, Osasco, Brazil) and reading was performed in an semi-automatic biochemistry analyzer (SBA-200, CELM, Sao Caetano do Sul, Brazil). The urinary allantoin and uric acid concentration were assessed by colorimetric method [17]. The absorbed purine derivatives $\left(\mathrm{PD}_{\mathrm{abs}}, \mathrm{mmol} / \mathrm{d}\right)$ were calculated as follows:

$$
\mathrm{PD}_{a b s}=\frac{\left(\mathrm{PD}-0.385 \times B W^{0.75}\right)}{(0.84)}
$$

In which: 0.84 represents the recovery of $\mathrm{PD}_{\mathrm{abs}}$ as $\mathrm{PD}$ and $0.385 \times \mathrm{BW}^{0.75}$ the endogenous excretion of PD [18].

Total urinary volume (L/d) was estimated by the ratio between creatinine excretion and creatinine concentration contained in the urine spot sample [19]. The nitrogen content in urine samples was determined according to AOAC [12], as previously described.

The ruminal synthesis of nitrogen compounds was calculated based on $\mathrm{PD}_{\mathrm{abs}}$ using the equation [18]:

$$
\text { Microbial N }=\frac{\left(70 \times \mathrm{PD}_{a b s}\right)}{(0.83 \times 0.134 \times 1,000)}
$$

Considering 70 as the $\mathrm{N}$ purine derivative content (mg N/ mol), 0.134 the ratio purine derivative $\mathrm{N}$ to microbial $\mathrm{N}$ [19], and 0.83 the intestinal digestibility of microbial purines [18].

On day 10 of each experimental period, blood samples were collected prior to the morning feeding by puncture of coccygeal vessels in vacutainers without clot activator (BD Vacutainer, Becton, Dickinson and Company, Becton Drive Franklin Lakes, NJ, USA). Blood samples were left resting in room temperature until clot formation and then centrifuged at 2,000 $\times$ g for $15 \mathrm{~min}$ at $4^{\circ} \mathrm{C}$. The supernatant was transferred to labeled plastic tubes and stored at $-20^{\circ} \mathrm{C}$ until analyses. Blood serum was analyzed for glucose (Laborlab 02200) and urea (Laborlab 02800) using commercial kits (Laborlab, Brazil), and the reading was performed in a semi-automatic biochemistry analyzer (SBA-200, CELM, Brazil).

Data were submitted to the MIXED procedure of SAS (Statistical Analysis System for Windows 9.3, SAS Institute Inc., Cary, NC, USA), after verifying the normality of residuals and homogeneity of variances using the UNIVARIATE procedure according to the model (except for ruminal parameters):

$$
\mathrm{Y}_{j k l m}=\mu+\mathrm{P}_{j}+\mathrm{T}_{k}+\mathrm{Q}_{l}+\mathrm{S}_{m}\left(\mathrm{Q}_{l}\right)+\mathrm{e}_{j k l m}
$$

Where: $\mathrm{Y}_{j k l m}=$ dependent variable; $\mu=$ overall mean; $\mathrm{P}_{j}=$ fixed effect of period $(j=1$ to 4$)$; $\mathrm{T}_{k}=$ fixed effect of treatment $(k=1$ to 4$) ; \mathrm{Q}_{l}=$ fixed effect of square $(l=1$ to 2$) ; \mathrm{s}_{m}\left(\mathrm{Q}_{l}\right)=$ random effect of steer within square $(i=1$ to 8$)$; and $\mathrm{e}_{j k l m}=$ residual error.

Ruminal fermentation data $\left(\mathrm{pH}, \mathrm{NH}_{3}-\mathrm{N}\right.$, and SCFA) were analyzed as repeated measures using the MIXED procedure of SAS (SAS Institute Inc.) according to the model: 


$$
\begin{aligned}
\mathrm{Y}_{i j k m}= & \mu+\mathrm{P}_{j}+\mathrm{T}_{k}+\mathrm{Q}_{l}+\mathrm{s}_{m}\left(\mathrm{Q}_{l}\right)+\mathrm{e}(\mathrm{a})_{i j k l m}+\mathrm{H}_{n} \\
& +\mathrm{P}_{j} \times \mathrm{H}_{n}+\mathrm{T}_{k} \times \mathrm{H}_{n}+\mathrm{Q}_{l} \times \mathrm{H}_{n}+\mathrm{s}_{m} \times \mathrm{H}_{n}+\mathrm{e}(\mathrm{b})_{i j k l m n}
\end{aligned}
$$

In which: $\mathrm{Y}_{i j k l m}=$ dependent variable; $\mu=$ overall mean; $\mathrm{P}_{j}=$ fixed effect of period ( $j=1$ to 4$) ; \mathrm{T}_{k}=$ fixed effect of treatment $(k=1$ to 4$) ; \mathrm{Q}_{l}=$ fixed effect of square $(l=1$ to 2$) ; \mathrm{s}_{m}\left(\mathrm{Q}_{l}\right)=$ random effect of steer within square $(m l=1$ to 8$)$; $\mathrm{e}(\mathrm{a})_{i j k l m}=$ residual error of main plot (a); $\mathrm{H}_{n}=$ fixed effect of time $(n=0,2,4,6,8,10$, or $12 \mathrm{~h}$ relative to the morning feeding); $\mathrm{P}_{j} \times \mathrm{H}_{n}=$ period by time fixed effect; $\mathrm{T}_{k} \times \mathrm{H}_{n}=$ treatment by time fixed effect; $\mathrm{Q}_{l} \times \mathrm{H}_{n}$ $=$ square by time fixed effect; $\mathrm{s}_{m} \times \mathrm{H}_{n}=$ steer by time random effect; and $\mathrm{e}(\mathrm{b})_{i j k l m n}=$ residual error of subplot (b). To determine differences among treatments, orthogonal contrasts were performed: $\mathrm{C} 1=\mathrm{CON}$ vs diets containing urea (U2+SRA1+SRA2), $\mathrm{C} 2=\mathrm{U} 2$ vs SRA2 $+\mathrm{SRB} 2$, and $\mathrm{C} 3=\mathrm{SRA} 2$ vs SRB2. The covariance structure was chosen based on the smallest Akaike's information criterion values. Means were adjusted by LSMEANS and significance level was set at $\mathrm{p} \leq 0.05$.

\section{Experiment 2}

Eighty-four Nellore steers (18-mo age, and $350.5 \pm 26.5 \mathrm{~kg}$ initial $\mathrm{BW}$, mean $\pm \mathrm{SD}$ ) were distributed into seven groups according to the initial $\mathrm{BW}$, and groups were randomly assigned to receive one of the experimental diets: control (CON), feed grade urea at 10 or $20 \mathrm{~g} / \mathrm{kg}$ diet DM (U1 and U2, respectively; Reforce N, Petrobras, Rio de Janeiro, Brazil), coated SRA2 at 10 or $20 \mathrm{~g} / \mathrm{kg}$ diet DM (SRA1 and SRA2, respectively; Polymer-coated slowrelease urea without sulphur in composition Petrobras), and coated slow-release urea B at 10 or $20 \mathrm{~g} / \mathrm{kg}$ diet DM (SRB1 and SRB2, respectively; Polymer coated slow-release urea with 29.5 $\mathrm{g} / \mathrm{kg}$ DM of sulphur content, Petrobras). Both experiments (Exp 1 and Exp 2) used similar urea sources. Diets (Table 2) were fed once daily $(0700 \mathrm{~h})$ as a total mixed ratio, and formulated to an ADG of $1.5 \mathrm{~kg}$ for a Bos indicus with $400 \mathrm{~kg}$ BW according to the NRC [11]. Animals were allocated in 7 pens $\left(30 \mathrm{~m}^{2}\right.$ per animal) with free access to water, shade and $6 \mathrm{~m}$ of a linear feed bunk. The area next from feed bunk was covered and concreted.

Animals were fed $110 \%$ of expected DM intake and refusals were weighed daily. At the start of experiment and on day 84, animals (12 h fasting) were weighed in a livestock scale for large animals. After 84 days of feedlot, animals were slaughtered (18 $\mathrm{h}$ fasting) in a commercial slaughter plant (Angeleli, Piracicaba, Brazil). Throughout the slaughtering, animals were submitted to brain concussion, bloodletting by section of jugular vessels and evisceration. The carcasses of steers were divided in two halves, which were maintained in a cold chamber for $24 \mathrm{~h}$. Samples from the longissimus lumborum muscle ( $2.5 \mathrm{~cm}$ thick) of the right half of carcasses were collected between 12th to 13th ribs to determine rib-eye area and backfat thickness using a checkered grid and a digital caliper rule, respectively [20].

Data were analyzed by the MIXED procedure of SAS (SAS Institute Inc., USA), verifying the normality of residuals and homogeneity of variances using the UNIVARIATE procedure using the model bellow:

$$
\mathrm{Y}_{i j}=\mu+\mathrm{T}_{i}+\mathrm{a}_{j}+\mathrm{e}_{i j w}
$$

\begin{tabular}{|c|c|c|c|c|c|c|c|}
\hline \multirow{2}{*}{ Item } & \multicolumn{7}{|c|}{ Diet $^{1)}$} \\
\hline & CON & U1 & U2 & SRA1 & SRA2 & SRB1 & SRB2 \\
\hline \multicolumn{8}{|l|}{ Ingredient (\%) } \\
\hline Ground corn & 31.2 & 38.5 & 44.1 & 38.5 & 44.1 & 38.5 & 44.1 \\
\hline Soybean meal $48 \% \mathrm{CP}$ & 10.6 & 3.50 & & 3.50 & & 3.50 & \\
\hline Whole raw soybean & 5.80 & 4.80 & 1.70 & 4.80 & 1.70 & 4.80 & 1.70 \\
\hline Slow-release urea B & & & & & & 1.00 & 2.00 \\
\hline Mineral premix ${ }^{3)}$ & 1.98 & 1.98 & 1.98 & 1.98 & 1.98 & 1.98 & 1.98 \\
\hline Limestone & 0.11 & 0.11 & 0.11 & 0.11 & 0.11 & 0.11 & 0.11 \\
\hline Salt & 0.11 & 0.11 & 0.11 & 0.11 & 0.11 & 0.11 & 0.11 \\
\hline \multicolumn{8}{|c|}{ Chemical composition (\% DM) } \\
\hline Ether extract & 3.60 & 3.43 & 2.81 & 3.43 & 2.81 & 3.43 & 2.81 \\
\hline
\end{tabular}

Table 2. Ingredients and chemical composition of experimental diets (Experiment 2) 
Table 3. Influence of polymer-coated slow release urea on nutrient intake and total tract digestion of Nellore steers (Experiment 1)

\begin{tabular}{|c|c|c|c|c|c|c|c|c|}
\hline \multirow{2}{*}{ Item } & \multicolumn{4}{|c|}{ Diet $^{1)}$} & \multirow{2}{*}{ SEM } & \multicolumn{3}{|c|}{ p-value ${ }^{2)}$} \\
\hline & CON & $\mathrm{U} 2$ & SRA2 & SRB2 & & $\mathrm{C} 1$ & $\mathrm{C} 2$ & C3 \\
\hline \multicolumn{9}{|l|}{ Intake $(\mathrm{kg} / \mathrm{d})$} \\
\hline Dry matter & 8.46 & 7.90 & 8.04 & 7.55 & 0.22 & 0.03 & 0.70 & 0.13 \\
\hline Neutral detergent fiber & 2.79 & 2.55 & 2.62 & 2.53 & 0.06 & 0.04 & 0.81 & 0.49 \\
\hline Crude protein & 1.31 & 1.21 & 1.23 & 1.12 & 0.03 & 0.01 & 0.41 & 0.05 \\
\hline Ether extract & 0.32 & 0.24 & 0.24 & 0.23 & 0.01 & $<0.01$ & 0.38 & 0.21 \\
\hline \multicolumn{9}{|c|}{ Total tract apparent digestibility coefficient } \\
\hline Dry matter & 0.66 & 0.70 & 0.66 & 0.72 & 0.01 & 0.13 & 0.70 & 0.02 \\
\hline Neutral detergent fiber & 0.59 & 0.62 & 0.57 & 0.62 & 0.02 & 0.56 & 0.39 & 0.14 \\
\hline Crude protein & 0.64 & 0.73 & 0.67 & 0.74 & 0.01 & $<0.01$ & 0.12 & 0.01 \\
\hline Ether extract & 0.86 & 0.85 & 0.87 & 0.89 & 0.01 & 0.54 & 0.17 & 0.55 \\
\hline
\end{tabular}

SEM, standard error of the mean; DM, dry matter.

1) Control, CON; U2, $20 \mathrm{~g} / \mathrm{kg}$ DM of feed grade urea; SRA2, $20 \mathrm{~g} / \mathrm{kg}$ DM of polymer-coated slow release A; SRB2, $20 \mathrm{~g} / \mathrm{kg}$ DM of polymer coated slow release B.

${ }^{2)}$ Orthogonal contrasts: C1, CON vs diets containing urea (U2+SRA1+SRA2); C2, U2 vs SRA2+SRB2; C3, SRA2 vs SRB2.

In which: $Y_{i j k}=$ dependent variable, $\mu=$ overall mean, $T_{i}=$ fixed effect of treatment ( $i=1$ to 7 ), $\mathrm{a}_{j}=$ random effect of animal $(j=1$ to 84$)$, and $\mathrm{e}_{i j}=$ residual error. The initial BW was used for covariate adjustment.

Differences among treatments were evaluated by orthogonal contrasts as follows: $\mathrm{C} 1$ : $\mathrm{CON}$ vs diets containing urea $(\mathrm{U} 1+\mathrm{U} 2+\mathrm{SRA} 1+\mathrm{SRA} 2+\mathrm{SRB} 1+\mathrm{SRB} 2), \mathrm{C} 2$ : feed grade urea $(\mathrm{U} 1+\mathrm{U} 2)$ vs polymer-coated slow-release urea (SRA1+SRA2+SRB1+SRB2), C3: CON vs diets containing $10 \mathrm{~g} / \mathrm{kg}$ DM of urea (U1+SRA1+SRB1), C4: CON vs diets containing $20 \mathrm{~g} / \mathrm{kg}$ $\mathrm{DM}$ of urea (U2+SRA2+SRB2), C5: diets containing $10 \mathrm{~g} / \mathrm{kg}$ $\mathrm{DM}$ of urea vs. diets containing $20 \mathrm{~g} / \mathrm{kg} \mathrm{DM}$ of urea, and C6: diets containing SRA (SRA1+SRA2) vs diets containing SRB (SRB1+SRB2). Differences were considered significant when $\mathrm{p} \leq 0.05$.

\section{RESULTS}

\section{Experiment 1}

Diets containing urea (U2, SRA2, and SRB2) decreased DM, NDF, CP, and EE intake (Table 3). However, diets containing urea did not affect the total tract apparent digestibility of nutrients except for $\mathrm{CP}$, which was increased $(\mathrm{p}<0.01)$ when diets containing urea were supplied. Polymer-coated slow-release urea sources showed similar nutrient intake and total tract apparent digestibility compared to feed grade urea. Despite the lower $(\mathrm{p}=0.05)$ CP intake of animals fed SRB2 compared to those fed SRA2, animals fed SRB2 showed higher total tract apparent digestibility of DM, non-fiber carbohydrate, and CP compared to those fed SRA2.

The dietary inclusion of urea did not affect the ruminal fermentation, including $\mathrm{NH}_{3}-\mathrm{N}$ concentration ( $\mathrm{p}=0.13$, Table 4). Slow-release urea sources showed lower $(\mathrm{p}=0.01) \mathrm{NH}_{3}-\mathrm{N}$ concentration compared to feed grade urea. In addition, slowrelease urea sources increased $(\mathrm{p} \leq 0.02)$ the propionate $(\mathrm{mmol}$ and $\mathrm{mol} / 100 \mathrm{~mol}$ ) and decreased $(\mathrm{p}=0.01)$ acetate to propionate ratio compared to feed grade urea. Furthermore, animals fed SRB2 had lower $(\mathrm{p}=0.04) \mathrm{NH}_{3}-\mathrm{N}$ concentration compared

Table 4. Influence of polymer-coated slow release urea on ruminal fermentation parameters of Nellore steers (Experiment 1) ${ }^{11}$

\begin{tabular}{|c|c|c|c|c|c|c|c|c|c|c|c|}
\hline \multirow{2}{*}{ Item } & \multicolumn{4}{|c|}{$\operatorname{Diet}^{2)}$} & \multirow{2}{*}{ SEM } & \multicolumn{6}{|c|}{ p-value ${ }^{3)}$} \\
\hline & CON & U2 & SRA2 & SRB2 & & Diet & Time & INT & $\mathrm{C} 1$ & $\mathrm{C} 2$ & C3 \\
\hline $\mathrm{pH}$ & SEM & 6.45 & 6.41 & 6.40 & 0.05 & 0.67 & $<0.01$ & 0.72 & 0.98 & 0.24 & 0.64 \\
\hline $\mathrm{NH}_{3}-\mathrm{N}(\mathrm{mg} / \mathrm{dL})$ & 17.9 & 24.0 & 20.7 & 16.4 & 1.60 & 0.01 & $<0.01$ & 0.36 & 0.13 & 0.01 & 0.04 \\
\hline Total SCFA (mmol) & 115 & 111 & 113 & 110 & 2.89 & 0.32 & $<0.01$ & 0.91 & 0.14 & 0.65 & 0.26 \\
\hline Acetate (mmol) & 78.2 & 75.9 & 76.9 & 74.7 & 1.84 & 0.25 & $<0.01$ & 0.94 & 0.10 & 0.94 & 0.21 \\
\hline Propionate (mmol) & 24.8 & 23.4 & 25.1 & 24.4 & 0.84 & 0.11 & $<0.01$ & 0.87 & 0.64 & 0.02 & 0.37 \\
\hline Butyrate (mmol) & 11.8 & 11.4 & 11.0 & 11.0 & 0.50 & 0.53 & $<0.01$ & 0.84 & 0.23 & 0.38 & 0.88 \\
\hline Acetate (mol/100 mol) & 68.4 & 68.8 & 68.3 & 68.2 & 0.45 & 0.36 & $<0.01$ & 0.98 & 0.79 & 0.07 & 0.92 \\
\hline Propionate (mol/100 mol) & 21.4 & 20.9 & 22.1 & 21.8 & 0.35 & 0.02 & $<0.01$ & 0.96 & 0.42 & 0.01 & 0.62 \\
\hline Butyrate (mol/100 mol) & 10.1 & 10.1 & 9.6 & 9.9 & 0.29 & 0.60 & $<0.01$ & 0.76 & 0.57 & 0.30 & 0.51 \\
\hline Acetate to propionate ratio & 3.24 & 3.36 & 3.14 & 3.20 & 0.07 & 0.02 & $<0.01$ & 0.99 & 0.72 & 0.01 & 0.50 \\
\hline
\end{tabular}

SEM, standard error of the mean; SCFA, short-chain fatty acids; DM, dry matter.

1) The values presented in the table above are the average values of each parameter from all rumen fluid sampling times $(0,2,4,6,8,10$ and $12 \mathrm{~h}$ relative to the morning feeding).

2) Control, CON; U2, $20 \mathrm{~g} / \mathrm{kg}$ DM of feed grade urea; SRA2, $20 \mathrm{~g} / \mathrm{kg}$ DM of polymer-coated slow release A; SRB2, $20 \mathrm{~g} / \mathrm{kg}$ DM of polymer coated slow release B.

${ }^{3)}$ INT, diet $\times$ time (h) interaction; orthogonal contrasts: C1, CON vs diets containing urea (U2+SRA1+SRA2); C2, U2 vS SRA2+SRB2; C3, SRA2 vs SRB2. 
Table 5. Influence of polymer-coated slow release urea on nitrogen utilization, microbial protein synthesis, and serum metabolites of Nellore steers (Experiment 1)

\begin{tabular}{|c|c|c|c|c|c|c|c|c|}
\hline \multirow{2}{*}{ Item } & \multicolumn{4}{|c|}{ Diet $^{1)}$} & \multirow{2}{*}{ SEM } & \multicolumn{3}{|c|}{ p-value $e^{2)}$} \\
\hline & CON & U2 & SRA2 & SRB2 & & $\mathrm{C} 1$ & $\mathrm{C} 2$ & C3 \\
\hline $\mathrm{N}$ intake $(\mathrm{g} / \mathrm{d})$ & 212 & 194 & 197 & 179 & 6.00 & 0.01 & 0.41 & 0.04 \\
\hline Fecal N (g/d) & 77.1 & 51.2 & 65.4 & 48.4 & 3.66 & $<0.01$ & 0.17 & 0.01 \\
\hline Urinary N (g/d) & 64.4 & 73.5 & 63.3 & 55.0 & 3.00 & 0.93 & 0.02 & 0.23 \\
\hline Microbial crude protein (g/d) & 538 & 403 & 542 & 434 & 35.1 & 0.34 & 0.66 & 0.17 \\
\hline Blood glucose (mg/dL) & 79.9 & 84.4 & 83.5 & 84.2 & 1.65 & 0.08 & 0.84 & 0.79 \\
\hline Blood urea (mg/dL) & 34.6 & 37.5 & 35.2 & 35.8 & 1.94 & 0.25 & 0.04 & 0.06 \\
\hline
\end{tabular}

SEM, standard error of the mean; DM, dry matter.

1) Control, CON; U2, $20 \mathrm{~g} / \mathrm{kg}$ DM of feed grade urea; SRA2, $20 \mathrm{~g} / \mathrm{kg}$ DM of polymer-coated slow release A; SRB2, $20 \mathrm{~g} / \mathrm{kg}$ DM of polymer coated slow release B.

${ }^{2)}$ Orthogonal contrasts: C1, CON vs diets containing urea (U2+SRA1+SRA2); C2, U2 vs SRA2+SRB2; C3, SRA2 vs SRB2.

to those fed SRA2 (16.4 vs $20.7 \mathrm{mg} / \mathrm{dL}$, respectively).

Diets containing urea decreased $(\mathrm{p} \leq 0.01) \mathrm{N}$ intake and fecal $\mathrm{N}$ excretion of steers (Table 5). Slow-release urea sources showed lower $(\mathrm{p}=0.02)$ urinary $\mathrm{N}$ excretion compared to feed grade urea. In addition, slow-release urea sources exhibited lower $(\mathrm{p}=0.04)$ blood urea concentration compared to feed grade urea. Finally, animals fed SRB2 had lower $(\mathrm{p} \leq 0.01) \mathrm{N}$ intake and fecal $\mathrm{N}$ excretion compared to those fed SRA2. Diets did not affect $(\mathrm{p} \geq 0.17)$ microbial protein synthesis.

\section{Experiment 2}

Inclusion of urea in diets, regardless of the source and amounts, decreased ( $p=0.01$ ) the final BW and ADG compared to CON (Table 6). Animals fed urea at $20 \mathrm{~g} / \mathrm{kg}$ DM (U2, SRA2 and SRB2) had lower $(\mathrm{p}<0.01)$ final BW and ADG compared to those fed urea at $10 \mathrm{~g} / \mathrm{kg}$ DM (U1, SRA1 and SRB1). No differences were observed in the carcass traits (rib-eye area and backfat thickness) assessed in the current experiment.

\section{DISCUSSION}

In the current experiment, the addition of urea at $20 \mathrm{~g} / \mathrm{kg} \mathrm{DM}$ declined the nutrient intake of steers. The reason for a decreased nutrient intake is not clear, since the nutrient apparent digestibility and ruminal fermentation were not largely affected by urea. Furthermore, animals showed a similar blood urea concentration, and the possibility of animal intoxication by ammonia can be discarded. However, the hepatic urea metabolism may increase the oxidative metabolism in the liver, enhancing the ATP production affecting the feed intake of ruminants [21-22]. Authors also suggested that feed grade urea could decrease DM intake when feeding at levels above $20 \mathrm{~g} / \mathrm{kg}$ DM due to its low acceptability by cattle [23]. The results in literature with urea addition to ruminant diets are varying, whereas some authors reported decreased nutrient intake without differences on apparent digestibility [29], other authors observed no differences on DM intake and digestibility when feeding urea up to $19.5 \mathrm{~g} / \mathrm{kg}$ DM to beef steers [24].

Feeding urea increased the apparent digestibility of $\mathrm{CP}$ because of lower $\mathrm{CP}$ intake compared to $\mathrm{CON}$ and due to the rapid urea solubilization in the rumen which favors its utilization by ruminal microorganisms $[5,25]$. The animals fed SRB2 had higher digestibility of DM and CP compared to those fed SRA2 and this result may be attributed to the product compositions. The difference between the products is their sulphur content, that is absent in SRA and its content in SRB is $29.5 \mathrm{~g} / \mathrm{kg} \mathrm{DM}$. Sulphur supplements can enhance the nutrient digestibility because the synthesis of amino acids that contain sulphur is critical for microbial growth [26-27]. Nevertheless, we did not detect differences on microbial protein synthesis agreeing with

Table 6. Influence of dose and different polymer-coated slow release urea on performance of Nellore steers (Experiment 2)

\begin{tabular}{|c|c|c|c|c|c|c|c|c|c|c|c|c|c|c|}
\hline \multirow{2}{*}{ Item } & \multicolumn{7}{|c|}{ Diet $^{1)}$} & \multirow{2}{*}{ SEM } & \multicolumn{6}{|c|}{ p-value $e^{2)}$} \\
\hline & CON & U1 & U2 & SRA1 & SRA2 & SRB1 & SRB2 & & $\mathrm{C} 1$ & $\mathrm{C} 2$ & $\mathrm{C3}$ & $\mathrm{C} 4$ & C5 & $\mathrm{C} 6$ \\
\hline Dry matter intake $(\mathrm{kg} / \mathrm{d})$ & 11.1 & 9.67 & 8.34 & 9.49 & 9.20 & 9.61 & 9.54 & & & & & & & \\
\hline Initial body weight (kg) & 352 & 349 & 345 & 353 & 352 & 356 & 353 & 3.4 & & & & & & \\
\hline Final body weight (kg) & 490 & 485 & 462 & 486 & 454 & 464 & 466 & 4.7 & 0.01 & 0.27 & 0.12 & $<0.01$ & 0.01 & 0.42 \\
\hline Average gain $(\mathrm{kg} / \mathrm{d})$ & 1.65 & 1.57 & 1.33 & 1.59 & 1.25 & 1.38 & 1.40 & 0.03 & 0.01 & 0.49 & 0.12 & $<0.01$ & 0.01 & 0.64 \\
\hline Rib-eye area $\left(\mathrm{cm}^{2}\right)$ & 67.7 & 68.2 & 66.8 & 68.3 & 65.4 & 68.4 & 71.7 & 0.88 & 0.87 & 0.64 & 0.83 & 0.93 & 0.85 & 0.18 \\
\hline Backfat thickness (mm) & 2.9 & 3.2 & 3.1 & 3.6 & 3.0 & 3.4 & 3.1 & 0.13 & 0.42 & 0.69 & 0.26 & 0.72 & 0.28 & 0.81 \\
\hline
\end{tabular}

SEM, standard error of the mean; DM, dry matter.

1) Control, CON; U1, $10 \mathrm{~g} / \mathrm{kg}$ DM of feed grade urea; U2, $20 \mathrm{~g} / \mathrm{kg}$ DM of feed grade urea; SRA1, $10 \mathrm{~g} / \mathrm{kg}$ DM of polymer-coated slow release urea A; SRA2, $20 \mathrm{~g} / \mathrm{kg}$ DM of polymer-coated slow release urea A; SRB1, $10 \mathrm{~g} / \mathrm{kg}$ DM of polymer-coated slow release urea B; SRB2, $20 \mathrm{~g} / \mathrm{kg}$ DM of polymer-coated slow release urea B.

${ }^{2)} \mathrm{C} 1$, CON vs diets containing urea (U1+U2+SRA1+SRA2+SRB1+SRB2); C2, feed grade urea (U1+U2) vs polymer-coated slow release urea (SRA1+SRA2+SRB1+ SRB2; C3, CON vs diets containing $10 \mathrm{~g} / \mathrm{kg}$ DM of urea (U1+SRA1+SRB1; C4, CON vs diets containing $20 \mathrm{~g} / \mathrm{kg}$ DM of urea (U2+SRA2+SRB2); C5, diets containing $10 \mathrm{~g} / \mathrm{kg}$ DM of urea vs diets containing $20 \mathrm{~g} / \mathrm{kg}$ DM of urea; 6 , diets containing SRA (SRA1+SRA2) vs diets containing SRB (SRB1+SRB2). 
[28] who reported no differences in purine derivatives production of Nellore steers fed the urea sources of the current study. In addition, Calomeni et al [9] found no differences in DM intake, apparent digestibility and microbial protein synthesis of dairy cows fed the same polymer-coated SRA as used in this study or feed grade urea, but the authors added $0.9 \mathrm{~g} / \mathrm{kg} \mathrm{DM}$ of the commercial products.

Interestingly, diets containing urea did not alter ruminal fermentation of steers. We expected that ammonia concentrations would increase when adding urea to the diets, because urea is rapidly degraded into ammonia in rumen and if it is not absorbed by epithelium or used to microbial protein synthesis, an increase of ruminal ammonia concentration may appear. Benedeti et al [29] also reported minimal differences of ruminal ammonia concentration in beef steers when replacing soybean meal by slow-release urea in a high concentrate diet. Animals fed the diets containing slow-release urea (SRA2 and SRB2) showed lower ammonia concentration in ruminal fluid compared to those fed feed grade urea, suggesting a decrease of urea hydrolysis in rumen or a greater nitrogen utilization by rumen microorganisms. The latter result was reported in in vitro [30], in situ [5], and in vivo studies [31]. Diets containing slow-release urea sources showed higher propionate compared to feed grade urea. Since the nutrient intake and digestibility were similar among diets containing urea, we suggest that the increase of propionate in rumen is related to the speed of urea release and greater utilization of nitrogen, which matches with the lower urinary nitrogen excretion and blood urea concentration of animals fed slow-release urea compared do those fed feed grade urea. Alvarez Almora et al [32] also reported an increase of ruminal propionate molar proportion when feeding beef steers with a slow-release urea compared to feed grade urea. The results observed in our study and Alvarez Almora et al [32] suggest a greater synchronization of fermentable carbohydrates and nitrogen in rumen, increasing rumen propionate and declining the urea blood concentration and urinary $\mathrm{N}$ excretion. The $\mathrm{N}$ intake of animals fed diets containing urea was lower compared to those fed CON, and this result is related to the negative effects of urea on DM intake. In addition, urea inclusion in diets decreased fecal $\mathrm{N}$ excretion due to the lower $\mathrm{CP}$ intake and higher $\mathrm{CP}$ total tract apparent digestibility compared to CON. Animals fed SRB2 had lower fecal N excretion due to the lower $\mathrm{N}$ intake and higher $\mathrm{CP}$ digestibility compared to those animals fed SRA2.

The Exp 2 evaluated the effects of polymer-coated slow-release urea (SRA and SRB) and levels of urea (10 or $20 \mathrm{~g} / \mathrm{kg}$ DM). Diets containing urea decreased the final BW and ADG possibly due to the negative effects of urea on nutrient intake reported in Exp 1. In agreement with the current study, Taylor-Edwards et al [33] found that increasing the dietary proportion of urea (feed grade urea or slow-release urea) decreased the ADG of beef steers, but the authors reported no differences on DM in- take. Interestingly, the inclusion of urea at $10 \mathrm{~g} / \mathrm{kg} \mathrm{DM}$ in steer diets did not alter the ADG, contrasting with Taylor-Edwards et al [33] who reported that the dietary inclusion of $4 \mathrm{~g} / \mathrm{kg} \mathrm{DM}$ and $16 \mathrm{~g} / \mathrm{kg} \mathrm{DM}$ of slow-release urea decreased the ADG of beef steers. Despite the differences in ADG, the rib-eye area and backfat thickness were not influenced by treatments. Few studies evaluated the effects of slow-release urea on carcass traits and all of them reported similar results to the current experiment $[8,34,35]$.

Urea in diets of beef steers at $20 \mathrm{~g} / \mathrm{kg}$ DM negatively influenced nutrient intake without largely affecting the nutrient digestibility except for the increase in $\mathrm{CP}$ digestibility. Polymercoated slow-release urea positively affected ruminal fermentation due to decrease of ammonia concentrations coupled with the increase of propionate production. Urea at $20 \mathrm{~g} / \mathrm{kg} \mathrm{DM}$, regardless of source, decreased ADG compared both to CON and diets with urea at $10 \mathrm{~g} / \mathrm{kg} \mathrm{DM}$.

\section{CONFLICT OF INTEREST}

We certify that there is no conflict of interest with any financial organization regarding the material discussed in the manuscript.

\section{ACKNOWLEDGMENTS}

The authors thank the University of São Paulo and Dairy Cattle Research Laboratory for providing the physical infrastructure and staff necessary for this study.

\section{REFERENCES}

1. Sinclair LA, Blake CW, Griffin P, Jones GH. The partial replacement of soybean meal and rapeseed meal with feed grade urea or a slowrelease urea and its effect on the performance and metabolism and digestibility in dairy cows. Animal 2012;6:920-7.

2. Ayasan T. Importance of milk urea nitrogen of dairy cow nutrition. J Agric Fac Gaziosmanpasa Univ 2009;26:27-33.

3. Galo E, Emanuele SM, Sniffen CJ, White JH, Knapp JR. Effects of a polymer coated urea product on nitrogen metabolism in lactating Holstein dairy cattle. J Dairy Sci 2003;86:2154-62.

4. Reynolds CK, Kristensen NB. Nitrogen recycling through the gut and the nitrogen economy of ruminants: An asynchronous symbiosis. J Anim Sci 2008;86:E293-E305.

5. Taylor-Edwards CC, Elam NA, Kitts SE et al. Influence of slowrelease urea on nitrogen balance and portal drained visceral nutrient flux in beef steers. J Anim Sci 2009;87:209-21.

6. Cherdthong A, Wanapat M, Wachipakorn C. Effects of urea-calcium mixture in concentrate containing high cassava chip on feed intake, rumen fermentation and performance of lactating dairy cows fed on rice straw. Livest Sci 2011;136:76-84.

7. Russell JB, O’Connor JD, Fox DG, Van Soest PJ, Sniffen CJ. A net carbohydrate and protein system for evaluating cattle diets: I. 
Ruminal fermentation. J Anim Sci 1992;70:3551-61.

8. Pinos-Rodríguez JM, Peña LY, González-Muñoz SS, Bárcena R, Salem A. Effects of a slow-release coated urea product on growth performance and ruminal fermentation in beef steers. Ital J Anim Sci 2010;9:e4.

9. Calomeni GD, Gardinal R, Venturelli BC et al. Effects of polymercoated slow-release urea on performance, ruminal fermentation, and blood metabolites in dairy cows. R Bras Zootec 2015;44:32734.

10. Valadares Filho SC, Broderick GA, Valadares RFD, Clayton MK. Effect of replacing alfalfa silage with high moisture corn on nutrient utilization and milk production. J Dairy Sci 2000;83:106-14.

11. NRC (National Research Council). Nutrient requirements of beef cattle. 7th rev. edn. Washington, DC: National Academies Press; 2000.

12. AOAC (Association of Official Analytical Chemists) International. Official Methods of Analysis. 17th edn. Arlington, VA: Association of Official Analytical Chemists, USA; 2000.

13. Van Soest PJ, Robertson JB, Lewis BA. Methods for dietary fibre, neutral detergent fibre and non-starch polysaccharides in relation to animal nutrition. J Dairy Sci 1991;74:3583-97.

14. Casali AO, Detmann E, Valadares Filho SC. Influence of incubation time and particles size on indigestible compounds contents in cattle feeds and feces obtained by in situ procedures. R Bras Zootec 2008; 37:335-42.

15. Vendramini THA, Takiya CS, Silva TH. Effects of a blend of essential oils, chitosan or monensin on nutrient intake and digestibility of lactating dairy cows. Anim Feed Sci Technol 2016;214:12-21.

16. Broderick GA, Kang JH. Automated simultaneous determination of ammonia and total amino acids in ruminal fluid and in vitro media. J Dairy Sci 1980;63:64-75.

17. Fujihara T, Orskov ER, Reeds PJ, Kyle DJ. The effect of protein infusion on urinary excretion of purine derivatives in ruminants nourished by intragastric nutrition. J Agric Sci 1987;109:7-12.

18. Chen XB, Gomes MJ. Estimation of Microbial Protein Supply to Sheep and Cattle Based on Urinary Excretion of Purine Derivatives - An Overview of Technical Details. Occasional Publication. Bucksburnd, Aberdeen, UK: International Feed Researches Unit, Rowett Research Institute; 1992.

19. Valadares RFD, Broderick GA, Valadares Filho SC, Clayton MK. Effect of replacing alfalfa silage with high moisture corn on ruminal protein synthesis estimated from excretion of total purine derivatives. J Dairy Sci 1999;82:2686-96.

20. Machado Neto OR, Ladeira MM, Chizzotti ML et al. Performance, carcass traits, meat quality and economic analysis of feedlot of young bulls fed oilseeds with and without supplementation of vitamin E. R Bras Zootec 2012;41:1756-63.

21. Xin HS, Schaefer DM, Liu QP, Axe DE, Meng QX. Effects of polyurethane coated urea supplement on in vitro ruminal fermentation, ammonia release dynamics and lactating performance of Holstein dairy cows fed a steam-flaked corn-based diet. Asian-Australas J Anim Sci 2010;23:491-500.

22. Santiago BT, Villela SDJ, Leonel FP. Slow-release urea in diets for lactating crossbred cows. R Bras Zootec 2015;44:193-9.

23. Wilson G, Martz FA, Campbell JR, Becker BA. Evaluation of factors responsible for reduced voluntary intake of urea diets for ruminants. J Anim Sci 1975;41:1431-7.

24. Rennó LN, Valadares Filho SC, Valadares RFD et al. Effects of feeding dietary urea levels on intake and total digestibility for steers of four genetic groups. R Bras Zootec 2015;34:1775-85.

25. Highstreet A, Robinson PH, Robinson J, Garret JG. Response of Holstein cows to replacing urea with a slowly rumen released urea in a diet high in soluble crude protein. Livest Sci 2010;129:179-85.

26. Leng RA. Factors affecting the utilization of 'poor-quality' forages by ruminants particularly under tropical conditions. Nutr Res Rev 1990;3:277-303.

27. Underwood EJ, Suttle NF. The Mineral Nutrition of Livestock. 3rd edn. Wallingford, Oxon, UK: CABI Publishing, CAB International; 1999.

28. Gardinal R, Gandra JR, Calomeni GD et al. Effects of polymer coated slow-release urea on ruminal fermentation and nutrient total tract digestion of beef steers. R Bras Zootec 2016;45:63-70.

29. Benedeti PDB, Paulino PVR, Marcondes MI et al. Soybean meal replaced by slow release urea in finishing diets for beef cattle. Livest Sci 2014;165:51-60.

30. Sinclair LA, Huntington JA, Wilde D. Partial replacement of soyabean meal and rapeseed meal with a slow release urea source (Optigen) and its effect on microbial growth and metabolism in vitro. Scarborough, UK: British Society of Animal Science. Annual Meeting; 2008. p. 228.

31. Holder VB, El-Kadi SW, Tricarico JM, Vanzant ES, Mcleod KR, Harmon DL. The effects of crude protein concentration and slow release urea on nitrogen metabolism in Holstein steers. Arch Anim Nutr 2013;67:93-103.

32. Alvarez Almora EG, Huntington GB, Burns JC. Effects of supplemental urea sources and feeding frequency on ruminal fermentation, fiber digestion, and nitrogen balance in beef steers. Anim Feed Sci Technol 2012;171:136-45.

33. Taylor-Edwards CC, Hibbard G, Kitts SE et al. Effects of slow-release urea on ruminal digesta characteristics and growth performance in beef steers. J Anim Sci 2009;87:200-8.

34. Tedeschi LO, Baker MJ, Ketchen DJ, Fox DG. Performance of growing and finishing cattle supplemented with a slow-release urea product and urea. Can. J Anim Sci 2002;82:567-73.

35. Bourg BM, Tedeschi LO, Wickersham TA, Tricarico JM. Effects of a slow-release urea product on performance, carcass characteristics, and nitrogen balance of steers fed steam-flaked corn. J Anim Sci 2012;90:3914-23. 